\title{
Emerging Energy-Efficient Technologies for Industry
}

\author{
Ernst Worrell \\ Nathan Martin \\ Lynn Price \\ Michael Ruth \\ Staff Scientist \\ Science \& Engineering Associate \\ Scientist \\ Principal Research Associate \\ Lawrence Berkeley National Laboratory \\ MS: 90-4000, One Cyclotron Road, Berkeley, CA 94720, USA \\ Neal Elliott \\ Anna Shipley \\ Jennifer Thorn \\ Senior Associate \\ Research Associate \\ Research Associate \\ American Council for an Energy Efficient Economy, \\ 1001 Connecticut Ave., NW, Suite 801, Washington, DC 20036, USA
}

\begin{abstract}
U.S. industry consumes approximately $37 \%$ of the nation's energy to produce $24 \%$ of the nation's GDP. Increasingly, society is confronted with the challenge of moving toward a cleaner, more sustainable path of production and consumption, while increasing global competitiveness. Technology is essential in achieving these challenges. We report on a recent analysis of emerging energy-efficient technologies for industry, focusing on over 50 selected technologies. The technologies are characterized with respect to energy efficiency, economics and environmental performance. This paper provides an overview of the results, demonstrating that we are not running out of technologies to improve energy efficiency, economic and environmental performance, and neither will we in the future. The study shows that many of the technologies have important nonenergy benefits, ranging from reduced environmental impact to improved productivity, and reduced capital costs compared to current technologies.
\end{abstract}

\section{INTRODUCTION}

In 1998 the American Council for an Energy Efficient Economy (ACEEE), Davis Energy Group and E-source published "Emerging Energy-saving Technologies and Practices for the Buildings Sector," which provided data on technologies with the largest potential savings, including likely costs, savings and date of commercialization (12). As that report and others like it demonstrate, the assessment of emerging technologies can be useful for identifying $R \& D$ projects, identifying potential technologies for market transformation activities, providing common information on technologies to a broad audience of policy-makers, and offering new insights into technology development and energy efficiency potentials.

Recently, there has been increasing interest in improving the assessment of emerging technologies with respect to the U.S. industrial sector. With the support of Pacific Gas and Electric Co. (PG\&E Co.) ${ }^{1}$, New York State Energy Research \& Development Authority, U.S. Department of Energy, U.S. Environmental Protection Agency, Northwest Energy Efficiency Alliance, and the Iowa Energy Center, staff from Lawrence Berkeley National Laboratory and ACEEE produced the report described in this paper (11). The goal of the report was to collect information on a broad array of potentially significant emerging energy-efficient industrial technologies and carefully characterize a subgroup of roughly 50 key technologies.

In the report our use of the term "emerging" denotes technologies which are both precommercial but near commercialization and technologies which have already entered the market but have less than $5 \%$ of current market share. We also have chosen technologies which are energy-efficient (ie. use less energy than existing technologies and practices to produce the same product), and may have additional so-called non-energy benefits.

\section{INDUSTRIAL ENERGY USE IN THE U.S.}

Industrial activities are still a key component of U.S. economic output. In 1997, industrial activities accounted for $24 \%$ of U.S. gross domestic product-U.S. GDP that year was $\$ 8,300$ billion — and employed 27 million full and part-time employees (4). Within the industrial

\footnotetext{
1 The PG\&E Co. program is funded by California utility customers and is administered by Pacific Gas and Electric Company under the auspices of the California Public Utilities Commission.
} 
sector, manufacturing activity, which consists of all industrial activity outside of agriculture, mining, and construction, accounts for $70 \%$ of industrial value added (4). In 1998, the United States consumed 94 Quadrillion Btu (99 EJ) of primary energy or $25 \%$ of world primary energy use (U.S. EIA, 2000). Within the various sectors of the U.S., the industrial sector remains a significant energy user, consuming nearly $40 \%$ of primary energy resources (Table 1). The industrial sector is extremely diverse and includes agriculture, mining, construction, energyintensive industries, and non-energy intensive manufacturing.

Energy is necessary to help our industries create useful products; however, we are increasingly confronted with the challenge of moving society toward a cleaner, more sustainable path of production and consumption. The development of cleaner, more energyefficient technologies can play a significant role in limiting the environmental impacts associated with many industries while enhancing productivity and reducing manufacturing costs.

The demand for energy to produce manufactured products is related to the volume of production as well as the efficiency of the equipment used in the manufacturing processes. A broad proxy for efficiency is its inverse, energy intensity, or the amount of energy required to produce a unit of output. Research about the U.S. has shown that since the first oil price shock in 1973 manufacturing energy consumption would have been significantly higher were it not for decreases in energy intensity. ${ }^{2}$ As long as they can remain competitive, businesses often will choose to operate existing equipment and technology throughout its useful lifetime, which can run for 20 years or more for large pieces of equipment such as cement kilns or blast furnaces. At some point, however, businesses are faced with investment in new capital stock. At this decision point, new and emerging technologies compete for capital investment alongside more established or mature technologies. Even if a standard technology is chosen, it is likely to be

\footnotetext{
${ }^{2}$ Golove and Schipper (1996) whose long term analysis of the U.S. manufacturing sector from 1958 to 1991 found that "declines in energy intensity played the dominant role in limiting actual energy consumption," while Belzer et al. (1995) found that energy intensity declines accounted for over half of the energy savings in the industrial sector.
}

more efficient than the equipment it is replacing. Understanding the dynamics of what drives these decisions to invest in the new and efficient technologies is important to better understand the drivers of technology change and their effect on industrial energy use. Barriers for technology transfer in the industrial sector include corporate decision-making rules, lack of information, limited capital availability, shortage of trained personnel (especially in small and medium sized enterprises), low energy prices, and the "invisibility" of energy savings.

Many new technologies follow a traditional "S" curve adoption path whereby a small segment of the industry known as early adopters, embraces a new and unproven technology despite high costs and potential risks. As the technology becomes more common, the perceived risks decrease and the cost of the technology declines. The period needed to achieve a significant market share may vary and depends on the technology characteristics, as well as characteristics of the market and the particular sector. Decanio and Laitner (5) point out that the current approaches to model technology diffusion tend to underestimate the rate since they do incorporate cost information (ie. an investment approach) but lack the representation of the influence of time and the impact of an increasingly critical mass of technology adopters (5). Figure 1 shows a typical " $S$ " curve of the adoption of continuous casting technology in the U.S. iron and steel industry. Although the technology eventually reached saturation, it took much longer in the U.S. than in other steel producing countries ${ }^{3}$.

\footnotetext{
${ }^{3}$ In Italy, and South Korea, and Japan for example 96\% or more of steel was continuously cast by 1993 , whereas only $85 \%$ was continuously cast in the U.S. at that time.
} 
Table 1 Historical Share of Industrial Primary Energy Use in the United States

\begin{tabular}{llcccc}
\hline & Units & $\mathbf{1 9 5 0}$ & $\mathbf{1 9 7 0}$ & $\mathbf{1 9 9 0}$ & $\mathbf{1 9 9 8}$ \\
Total U.S. & Quads (EJ) & $34.6(36.5)$ & $67.9(71.6)$ & $84.1(88.7)$ & $94.2(99.4)$ \\
Total Industry & Quads (EJ) & $16.2(17.1)$ & $29.6(31.3)$ & $32.1(33.9)$ & $35.4(37.4)$ \\
Percent share & $\%$ & $47 \%$ & $44 \%$ & $38 \%$ & $38 \%$ \\
\hline
\end{tabular}

Source: US EIA, 2000

Figure 1. Continuous casting use in the United States iron and steel industry, expressed as share of steel production (1970-1998)

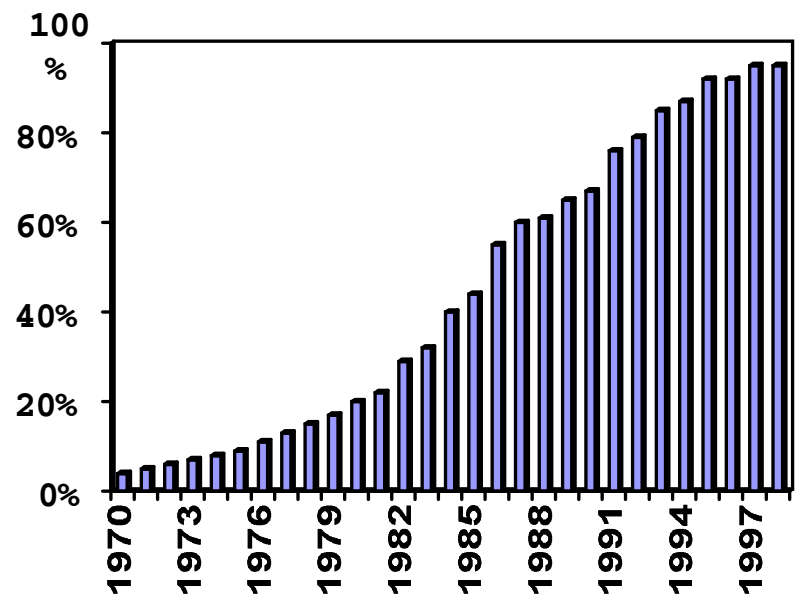

Source: IISI, 2000

Many innovation and energy polices focus on accelerating the rate of adoption of specific technologies, by reducing the costs or perceived risks of the technology. Various programs try to lower the barriers simultaneously in some steps. A wide array of policies, to increase the implementation rate of new technologies, has been used and tested in the industrial sector in industrialized countries with varying success rates. We will not discuss general programs and policies in this report but refer to the literature (see e.g. 1, 3, 10, 13). With respect to technology diffusion policies there is no single instrument to reduce the size of the barriers; instead, an integrated policy accounting for the characteristics of technologies, stakeholders and countries addressed is needed. Research, development, and demonstration projects often reduce risk and lower initial investment-costs. Market transformation programs lower the initial risk to technology developers by subsidizing the research and product development for more efficient technologies. "Demand-pull" programs seek to organize buyer groups to create a more ready market for emerging technologies. Financial incentive programs such as tax credits or other financial instruments seek to underwrite the first cost of the investment by the purchaser. 
Table 2. Example of summary table for near net shape casting in the steel industry.

Near net shape casting/strip casting

\section{steel-2}

Replace current continuous casting with direct near net shape casting

Market Information:

Industries

End-use(s)

Energy types

Market segment

2015 basecase use

Reference technology

Description

Throughput or annual op. hrs.

Electricity use

Fuel use

Primary energy use

New Measure Information:

Description

Electricity use

Fuel use

Primary Energy use

Current status

Date of commercialization

Est. avg. measure life

Savings Information:

Electricity savings

Fuel savings

Primary energy savings

Penetration rate

Feasible applications

Other key assumptions

Elec svgs potential in 2015

Fuel svgs potential in 2015

Primary energy svgs potential

in 2015

Cost Effectiveness

Investment cost

Type of cost

Change in other costs

Cost of saved energy (elec)

Cost of saved energy (fuel)

Cost of saved energy (primary)

Simple payback period

Internal rate of return

Key non energy factors

Productivity benefits

Product quality beneifts

Environmental benefits

Other benefits

Current promotional activity

Evaluation

Major market barriers

Likelihood of success

Recommended next steps

Data quality assessment

Sources:

2015 basecase

Basecase energy use

New measure energy savings

Lifetime

Feasible applications

Costs

Key non energy factors

\begin{tabular}{|l|r} 
& \multicolumn{2}{|c}{ Iron an } \\
& Process \\
& Gas, el \\
& N \\
\hline & 11 \\
\hline & \\
\hline & Continuous casting \\
\hline tons & \\
\hline kWh & 20 \\
\hline MBtu & 2 \\
\hline MBtu & 4 \\
\hline
\end{tabular}

Near net shape casting/thin strip casting

\begin{tabular}{l|c|l} 
kWh & 30 & Worrell et al., 1997, DeBeer, 1999
\end{tabular}

\begin{tabular}{l|l|l} 
MBtu & 0.3 & Worrell et al., 1997. DeBeer, 1999 estimates 0.0
\end{tabular}

MBtu 0.6

\begin{tabular}{|l|l|l}
\hline & Commercialized & Near net beams but not yet flat rolled products
\end{tabular}

\begin{tabular}{|l|c|c|}
\hline & \multicolumn{3}{|c|}{1995} \\
\hline Years & 20 \\
& & \\
\hline $\mathrm{kWh} / \%$ & 176 & $90 \%$ \\
\hline $\mathrm{MBtu} / \%$ & 2.5 & $90 \%$ \\
\hline $\mathrm{MBtu} / \%$ & 4.0 & $90 \%$ \\
\hline \multicolumn{2}{|c}{} & high \\
\hline$\%$ & $30 \%$ \\
\hline & 6093 \\
\hline GWh & 86 \\
\hline Tbtu & 137.6 \\
\hline Tbtu & \multicolumn{2}{|}{} \\
& \multicolumn{2}{|}{} \\
&
\end{tabular}

No flat rolled caster yet commercial

Worrell et al., 1999

Unit consumption presented. Casters range from 150 to $3,000 \mathrm{kton} / \mathrm{y}$

Worrell et al., 1999

Worrell et al., 1999

Worrell et al., 1999

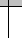

Apply to non high end steel products, Worrell et al.,1999

Savings applied to feasible applications for 2015 output

Savings applied to feasible applications for 2015 output

$6 \%$ savings. Primary energy consumption of 2144 TBtu in 2015

\begin{tabular}{|l|l|l|}
\hline 31 & Assume $15 \%$ less than conventional casting systems. Full retrofit cost \\
\hline
\end{tabular} $\$ 103$

\begin{tabular}{l|c|l}
$\$$ & -40 & Worrell et al. 1997
\end{tabular}

\begin{tabular}{l|l}
$\$ / \mathrm{kWh}$ & -0.20
\end{tabular}

\begin{tabular}{l|l} 
\$Mbtu & -14.19 \\
\hline
\end{tabular}

\begin{tabular}{l|l}
$\$ / \mathrm{Mbtu}$ & -8.85 \\
\hline
\end{tabular}

\begin{tabular}{l|l} 
Years & 0.6 \\
\hline & $157 \%$ \\
\hline
\end{tabular}

$\%$

0.6

(1)

Based on \$2/Mbtu average 1994 primary energy for steel

\begin{tabular}{|l|l} 
significant & reduced capital costs, reduced production time
\end{tabular}

somewhat $\quad$ improved surface properties

\begin{tabular}{l|l} 
somewhat & reduced emissions
\end{tabular}

\begin{tabular}{|c|c|c|}
\hline & somewhat & reduced emissions \\
\hline $\mathrm{H}, \mathrm{M}, \mathrm{L}$ & high & conferences, marketing by suppliers, research consortiums \\
\hline & technical challenges & Also, CSP flat rolling plants limited \\
\hline $\mathrm{H}, \mathrm{M}, \mathrm{L}$ & high & \\
\hline & $R \& D$ & \\
\hline$E, G, F, P$ & Good & Significant literature; limited field data \\
\hline & & EIA, 1999 \\
\hline & & Worrell et al. 1999 \\
\hline & & Worrell et al., 1997 \\
\hline & & Worrell et al. 1999 \\
\hline & & SMS, 1995; Tomasseti, 1995, Kuster, 1996 \\
\hline & & DeBeer, 1999 \\
\hline
\end{tabular}




\section{TECHNOLOGY SELECTION}

The project started with the identification of approximately 200 emerging industrial technologies through a review of the literature, international $R \& D$ programs, databases and studies. The review was not limited to U.S. experiences, but rather tried to produce an inventory of international technology developments. For an overview of the total list of technologies see Martin et al. (2000). Based on the literature review and the application of initial screening criteria, we identified and developed profiles for 54 technologies. The technologies themselves range from highly specific technologies that can be applied in a single industry to the more broadly cross-cutting technologies, which can be used in many industrial sectors.

Each of the selected technologies has been assessed with respect to energy efficiency characteristics, likely energy savings by 2015 , economics, environmental performance, as well as needs to further the development or implementation of the technology. The technology characterization includes a two-page description and a one-page table summarizing the results for the technology. Table 2 provides an example of the summary table for near net shape casting for the iron and steel industry. This technology combines casting and hot rolling, saving energy and increasing productivity. Several steel plants in the U.S. already use thin slab casting, the current commercial status of near net shape casting

\section{SUMMARY OF RESULTS}

Table 3 provides an overview of the 54 characterized emerging technologies. We have evaluated energy savings in two different ways. The third column of Table 3 (Total Energy Savings) shows the amount of total manufacturing energy that the technology is likely to save in 2015 in a businessas-usual scenario. The fourth column (Sector Savings) reflects the savings relative to expected energy use in the particular sector. We believe that both metrics are useful in evaluating the relative savings potential of various technologies.

Economic evaluation of the technology is identified in the summary table by simple payback period, defined as the initial investment costs divided by the value of energy savings less any changes in operations and maintenance costs. We chose this measure since it is frequently used as a shorthand evaluation metric among industrial energy managers. As the table notes, payback times for the technologies range from the immediate to 20 years or more. Of the 54 technologies profiled, 31 have estimated paybacks of 3 years or less

Energy savings are most often not the determining factor in the decision to develop or to invest in an emerging technology. Over two-thirds of technologies not only save energy but yield environmental or other benefits, so-called non-energy benefits. The non-energy benefits are pre-dominantly increases in productivity through reduced capital costs or increased throughput compared to state-ofthe-art technology.

Finally, technologies are not simply developed and then seamlessly enter existing markets. The acceptance of emerging technologies is often a slow process that entails active research and development, prototype development, market demonstration, and other activities. In Table 3 we summarize the recommendations for the primary activities that can be undertaken to increase the rate of uptake of these technologies. Over half have already been developed to prototype stage or are already commercial but require further demonstration and dissemination.

Depending on the particular technology and application, the technologies will reduce electricity consumption, fuel consumption, or both. Table 4 presents the technologies rated according to their primary energy savings (i.e., accounting for losses in the production and delivery of electricity). These savings values represent the estimated 2015 implemented savings under a business-as-usual scenario (i.e. excluding policy efforts to stimulate adoption of a specific technology). As would be expected, the cross-cutting technologies (motor systems, lighting, utilities) save the largest amount of primary energy, followed by selected specific technologies in the energy-intensive sectors (steel, petroleum, paper, aluminum, and chemicals). However, this does not mean that sector-specific technologies should be overlooked, as many of these may save substantial amounts of energy in a particular sector, or may have important additional benefits. 
Table 3. Summary of Profiled Emerging Industrial Technologies

\begin{tabular}{|c|c|c|c|c|c|c|c|}
\hline Technology & Sector & \begin{tabular}{|c|} 
Total \\
Energy \\
Savings $^{1}$ \\
\end{tabular} & $\begin{array}{c}\text { Sector } \\
\text { savings }^{2}\end{array}$ & $\begin{array}{c}\text { Simple } \\
\text { Payback }\end{array}$ & $\begin{array}{l}\text { Environ. } \\
\text { Benefits }\end{array}$ & $\begin{array}{c}\text { Other } \\
\text { Benefits }^{3} \\
\end{array}$ & $\begin{array}{c}\text { Suggested Next } \\
\text { Steps }\end{array}$ \\
\hline Advanced forming & aluminum & medium & low & Immed. & & $\mathrm{P}$ & R\&D \\
\hline Efficient cell retrofit designs & aluminum & high & high & 2.7 & somewhat & & dissemination \\
\hline Improved recycling technologies & aluminum & medium & low & 4.5 & significant & $\mathrm{P}$ & demonstration \\
\hline inert anodes/wetted cathodes & aluminum & high & high & 4.0 & significant & $\mathrm{P}$ & $R \& D$ \\
\hline Roller kiln & ceramics & medium & high & 1.9 & significant & $\mathrm{P}$ & demonstration \\
\hline Clean fractionation - celluose pulp & chemicals & low & low & 1.9 & significant & $\mathrm{P}$ & demonstration \\
\hline $\begin{array}{l}\text { Gas membrane technologies- } \\
\text { chemicals }\end{array}$ & chemicals & low & low & 10.2 & significant & $\mathrm{P}$ & dissemination \\
\hline Heat recovery technologies - chem. & chemicals & medium & low & 2.4 & & $\mathrm{P}$ & dissem., demo \\
\hline Levulinic acid from biomass (biofine) & chemicals & low & low & 1.5 & significant & $\mathrm{P}$ & demonstration \\
\hline Liquid mebrane technologies - chem. & chemicals & low & low & 11.2 & significant & & dissemination \\
\hline New catalysts & chemicals & low & low & 7.9 & somewhat & $\mathrm{P}$ & $R \& D$ \\
\hline Autothermal reforming-Ammonia & chemicals & high & low & 3.7 & significant & $\mathrm{P}$ & dissemination \\
\hline Plastics recovery & plastics & medium & low & 2.8 & compelling & & demonstration \\
\hline Continuous melt silicon crystal growth & electronics & medium & high & Immed. & somewhat & $\mathrm{Q}, \mathrm{P}$ & $R \& D$ \\
\hline Electron Beam Sterilization & food processing & high & high & 19.2 & & $\mathrm{P}, \mathrm{Q}$ & $R \& D$ \\
\hline Heat recovery - low temperature & food processing & medium & low & 4.8 & & & dissemination \\
\hline Membrane technology - food & food processing & high & high & 2.2 & somewhat & $\mathrm{P}, \mathrm{Q}$ & dissem., $R \& D$ \\
\hline Cooling and storage & food processing & medium & low & 2.6 & somewhat & $\mathrm{P}, \mathrm{Q}$ & dissem., demo \\
\hline $100 \%$ recycled glass cullet & glass & medium & high & 2.0 & significant & & demonstration \\
\hline Black liquor gasification & pulp and paper & high & high & 1.5 & somewhat & $\mathrm{S}$ & demonstration \\
\hline Condebelt drying & pulp and paper & high & low & 65.2 & & $\mathrm{P}$ & demonstration \\
\hline Direct electrolytic causticizing & pulp and paper & low & low & N/A & somewhat & & $R \& D$ \\
\hline Dry sheet forming & pulp and paper & medium & low & 20.3 & somewhat & & $\mathrm{R} \& \mathrm{D}$, demo \\
\hline Heat recovery - paper & pulp and paper & high & low & 1.8 & somewhat & & demonstration \\
\hline High Consistency forming & pulp and paper & high & high & Immed. & somewhat & & demonstration \\
\hline Impulse drying & pulp and paper & high & low & 20.3 & & $\mathrm{P}$ & demonstration \\
\hline Biodesulfurization & pet. refining & low & low & 1.8 & & & $\mathrm{R} \& \mathrm{D}$, demo \\
\hline Fouling minimization & pet. refining & high & high & $\mathrm{N} / \mathrm{A}$ & & $\mathrm{P}$ & $\mathrm{R} \& \mathrm{D}$ \\
\hline BOF gas and sensible heat recovery & iron and steel & medium & low & 14.7 & significant & & dissemination \\
\hline Near net shape casting/strip casting & iron and steel & high & high & Immed. & somewhat & $\mathrm{P}, \mathrm{Q}$ & $R \& D$ \\
\hline New EAF furnace processes & iron and steel & high & high & 0.3 & somewhat & $\mathrm{P}$ & field test \\
\hline Oxy-fuel combustion in reheat furnace & iron and steel & high & low & 1.2 & significant & & field test \\
\hline Smelting reduction processes & iron and steel & high & high & Immed. & significant & & demonstration \\
\hline Ultrasonic dying & textile & medium & low & 0.3 & compelling & $\mathrm{P}, \mathrm{Q}$ & demonstration \\
\hline Variable wall mining machine & mining & low & low & 10.6 & & $\mathrm{P}, \mathrm{S}$ & demonstration \\
\hline Hi-tech facilities HVAC & cross-cutting & medium & high & 4.0 & & $\mathrm{P}, \mathrm{Q}$ & disseminaiton \\
\hline Advanced lighting technologies & cross-cutting & high & high & 1.3 & & $\mathrm{Q}, \mathrm{P}, \mathrm{S}$ & dissem., demo \\
\hline Advanced lighting design & cross-cutting & high & high & 3.0 & & $\mathrm{P}, \mathrm{Q}, \mathrm{S}$ & dissem., demo \\
\hline Advance ASD designs & cross-cutting & high & low & 1.1 & & $\mathrm{P}$ & $R \& D$ \\
\hline Advanced compressor controls & cross-cutting & medium & low & 0.04 & & $\mathrm{Q}, \mathrm{P}$ & dissemination \\
\hline Compressed air system management & cross-cutting & high & high & 0.4 & & $\mathrm{Q}, \mathrm{P}$ & disseminaiton. \\
\hline Motor diagnostics & cross-cutting & low & low & Immed. & & $\mathrm{P}$ & dissem., demo \\
\hline Motor system optimization & cross-cutting & high & high & 1.5 & somewhat & $\mathrm{P}, \mathrm{Q}$ & dissem., training \\
\hline Pump efficiency improvement & cross-cutting & high & high & 3.0 & & $\mathrm{P}$ & dissem., training \\
\hline Switched reluctance motor & cross-cutting & medium & low & 7.4 & & $\mathrm{P}$ & $\mathrm{R} \& \mathrm{D}$ \\
\hline Advanced lubricants & cross-cutting & medium & low & 0.1 & significant & $\mathrm{P}$ & dissemination. \\
\hline Anearobic waste water treatment & cross-cutting & medium & low & 0.8 & significant & $\mathrm{P}$ & dissem., demo \\
\hline High efficiency/low Nox burners & cross-cutting & high & low & 3.1 & significant & $\mathrm{P}, \mathrm{Q}$ & dissem., demo \\
\hline Membrane technology wastewater & cross-cutting & high & low & 4.7 & significant & $\mathrm{P}$ & dissem., $R \& D$ \\
\hline Process Integration (pinch analysis) & cross-cutting & high & low & 2.3 & somewhat & $\mathrm{P}$ & dissemination \\
\hline Sensors and controls & cross-cutting & high & low & 2.0 & somewhat & $\mathrm{P}, \mathrm{Q}$ & $\begin{array}{l}\mathrm{R} \& \mathrm{D}, \text { demo, } \\
\text { dissem. }\end{array}$ \\
\hline Advanced CHP turbine systems & cross-cutting & high & high & 6.9 & significant & & policies \\
\hline Advanced reciprocating engines & cross-cutting & high & high & 8.3 & & $\mathrm{P}, \mathrm{Q}$ & $\mathrm{R} \& \mathrm{D}$, demo \\
\hline Fuel cells & cross-cutting & high & high & 58.6 & Significant & $P, Q$ & demonstration \\
\hline Microturbines & cross-cutting & high & low & Never & & $P, Q$ & R\&D, demo \\
\hline
\end{tabular}

Notes: 1 . "High" could save more than $0.1 \%$ of manufacturing energy use by 2015 , "medium" saves 0.01 to $0.1 \%$, and "low" saves less than $0.01 \%$. 2. "High" could save more than $1 \%$ of sector energy use by 2015 , "medium" saves 0.1 to $1 \%$, and "low" saves less than $0.1 \%$.

3. $\mathrm{P}=$ productivity, $\mathrm{Q}=$ quality, $\mathrm{S}=$ safety. 
Table 4. Projected 2015 Implemented Primary Energy Savings Potential

\begin{tabular}{|l|l|l|c|}
\hline Technology & Code & Sector & Savings (TBtu) \\
\hline Motor system optimization & Motorsys-5 & cross-cutting & 1502 \\
Advanced reciprocating engines & Utilities-2 & cross-cutting & 777 \\
Compressed air system management & Motorsys-3 & cross-cutting & 563 \\
Pump efficiency improvement & Motorsys-6 & cross-cutting & 502 \\
Advanced CHP turbine systems & Utilities-1 & cross-cutting & 484 \\
Advanced lighting design & Lighting-2 & cross-cutting & 408 \\
Advanced lighting technologies & Lighting-1 & cross-cutting & 231 \\
Fuel cells & Utilities-3 & cross-cutting & 185 \\
Near net shape casting/strip casting & Steel-2 & iron and steel & 138 \\
Sensors and controls & Other-5 & cross-cutting & 136 \\
Fouling minimization & Refin-2 & pet. refining & 123 \\
Membrane technology wastewater & Other-3 & cross-cutting & 118 \\
Microturbines & Utilities-4 & cross-cutting & 67 \\
Black liquor gasification & Paper-1 & pulp and paper & 64 \\
Efficient cell retrofit designs & Alum-2 & aluminum & 46 \\
Process Integration (pinch analysis) & Other-4 & cross-cutting & 38 \\
Autothermal reforming-Ammonia & Chem-7 & chemicals & 37 \\
Condebelt drying & Paper-2 & pulp and paper & 34 \\
Electron Beam Sterilization & food processing & 34 \\
Inert Anodes/Wetted Cathodes & Food-1 & aluminum & 34 \\
\hline
\end{tabular}

Electricity is a unique energy source, with a large infrastructure supporting its generation and delivery and significant emissions. Many, including electric utilities, will find it important to focus on technologies that save electricity. Table 5 identifies the top 15 technologies in terms of electricity savings. Our estimate of savings is based on an economically feasible market penetration in 2015 under business-as-usual conditions. As Table 5 indicates, the cross-cutting technologies concerning motor systems, lighting, and utilities are expected to have the most significant impact in terms of savings along with selected sector-specific technologies. The most important sector-specific technologies are black liquor gasification (a potentially large self-generation technology in the pulp and paper sector) and technologies that reduce electricity use in the aluminum sector and the electric arc furnace/secondary steel sectors. According to the U.S. Energy Information Administration, total forecast electricity use for the U.S. industrial sector in 2015 is 13,000 TWh (6). While the top technology only represents $1 \%$ of total forecast electricity use, this is still a significant amount, representing \$7 billion in electricity expenditures alone. Since electricity is one of the most high quality and expensive energy inputs, small reductions in electricity expenditures can have a large impact on reductions in operations costs for various manufacturing establishments.

Table 6 identifies the key technologies in terms of fuel savings. Unlike the electricity savings, the technologies highlighted in this table are primarily sector-specific, although crosscutting technologies (membranes, sensors, process integration) show strong potential for energy savings. The fuel savings below tend to reflect better utilization of low quality or by-product fuels, improved heat recovery, or better direct application of process heating. Similar to electricity savings, no one technology represents an overwhelming proportion of industrial fuel consumption in 2015 (estimated at 31,960 TBtu), but these are also significant representing a savings in energy expenditures between $\$ 30$ and $\$ 900$ million per year. 
Table 5. Projected 2015 Implemented Electricity Savings Potential

\begin{tabular}{|l|l|l|c|}
\hline Technology & Code & Sector & Savings (TWh) \\
\hline Motor system optimization & motorsys-5 & Cross-cutting & 176 \\
Advanced reciprocating engines & utilities-2 & Cross-cutting & 156 \\
Advanced CHP turbine systems & utilities-1 & Cross-cutting & 79 \\
Advance ASD designs & motorsys-1 & cross-cutting & 72 \\
Compressed air system management & motorsys-3 & cross-cutting & 66 \\
Fuel cells & utilities-3 & cross-cutting & 65 \\
Pump efficiency improvement & motorsys-6 & Cross-cutting & 59 \\
Advanced lighting technologies & lighting-1 & cross-cutting & 48 \\
Advanced lubricants & motorsys-8 & cross-cutting & 46 \\
Microturbines & utilities-4 & cross-cutting & 40 \\
Advanced lighting design & lighting-2 & cross-cutting & 27 \\
Black liquor gasification & paper-1 & pulp and paper & 10 \\
Advanced compressor controls & motorsys-2 & cross-cutting & 9 \\
Switched reluctance motor & motorsys-7 & cross-cutting & 7 \\
Near net shape casting/strip casting & steel-2 & iron and steel & 6 \\
Electron Beam Sterilization & food-1 & food processing & 5 \\
Efficient cell retrofit designs & alum-2 & aluminum & 4 \\
Inert anodes/wetted cathodes & alum-4 & aluminum & 3 \\
New EAF furnace processes & steel-3 & iron and steel & 3 \\
Hi-tech facilities HVAC & HVAC-1 & cross-cutting & 2 \\
\hline
\end{tabular}

Table 6. Projected 2015 Implemented Fuel Savings Potential

\begin{tabular}{|c|c|c|c|}
\hline Technology & Code & Sector & Savings TBtu \\
\hline Membrane technology wastewater & Other-3 & cross-cutting & 276 \\
\hline Fouling minimization & Refin-2 & pet. refining & 123 \\
\hline Sensors and controls & other-5 & cross-cutting & 111 \\
\hline Near net shape casting/strip casting & steel-2 & iron and steel & 86 \\
\hline Impulse drying & paper-7 & pulp and paper & 64 \\
\hline Autothermal reforming-Ammonia & chem-7 & chemicals & 38 \\
\hline Process Integration (pinch analysis) & other-4 & cross-cutting & 37 \\
\hline Membrane technology - food & food-3 & food processing & 36 \\
\hline Condebelt drying & paper-2 & pulp and paper & 34 \\
\hline Smelting reduction processes & steel-5 & iron and steel & 32 \\
\hline Dry sheet forming & paper-4 & pulp and paper & 28 \\
\hline Oxy-fuel combustion in reheat furnace & steel-4 & iron and steel & 23 \\
\hline High efficiency/low NOx burners & other-2 & cross-cutting & 21 \\
\hline Heat recovery - paper & paper-5 & pulp and paper & 20 \\
\hline
\end{tabular}

\section{Suggested Actions}

Each technology is at a different point in the development or commercialization process. Some technologies still need further R\&D to address cost or performance issues. Other technologies are ready for demonstration. Some technologies have already proven themselves in the field, and the market needs to be informed on the benefits and market channels needed to develop skills to deliver the technology. Table 1 outlined the recommendations to support future development of the technologies. We note that this is not an endorsement of any particular technology. This is an issue that will ultimately be decided by the technology purchasers and users. However, the actions are intended to help identify whether a technology is both technically and economically viable and whether it is robust enough to accommodate the stringent product quality demands in various manufacturing establishments.

Seventeen emerging technologies could benefit from additional R\&D. We suggest further R\&D for several primary metal technologies (e.g. advanced forming, inert anodes/wetted cathodes in aluminum and near net shape casting in steel), several crosscutting motor and utility technologies (e.g. advanced ASD designs, switched reluctance motor, advanced reciprocating engines, micro-turbines, sensors and controls). In addition to private research funds, several of the identified technologies have received some R\&D support from the U.S. Department of Energy or other public entities, including federal and state agencies. 
There are, however, a large number of technologies that already have made some headway into the marketplace or are at the prototype testing stage, and candidates for demonstration for potential customers to gain comfort with the technology. While we recommend further demonstration and dissemination of the technology, it is often difficult to understand what is limiting their uptake without more comprehensive investigation of market issues. Some of the technologies in this category are common in European countries or Japan but have not yet penetrated the U.S. market. Others are being newly developed in the U.S. and face challenges in reducing the perceived risks by investors. Two technologies, motor system optimization and pump efficiency improvement are opportunity for training programs similar to those developed by the U.S. Department of Energy for the compressed air system management. For advanced industrial CHP turbine systems the major recommended activity is removal of policy barriers. For others, their unique markets will dictate the form of the educational and promotional activities. We urge the reader to follow up on any details in the specific technology profiles.

\section{CONCLUSIONS AND FUTURE WORK}

For this study, we identified about 175 emerging energy-efficient technologies in industry, of which we characterized 54 in detail. While many profiles of individual emerging technologies are available, few reports have attempted to impose a standardized approach to the evaluation of the technologies. This study provides a way to review technologies in an independent manner, based on information on energy savings, economic, non-energy benefits, major market barriers, likelihood of success, and suggested next steps to accelerate deployment of each of the analyzed technologies.

There are many interesting lessons to be learned from further investigation of technologies identified in our preliminary screening analysis. The detailed assessments of the 54 technologies are useful to evaluate claims made by developers, as well as to evaluate market potentials for the United States or specific regions. In this report we show that many new technologies are ready to enter the market place, or are currently under development, demonstrating that the United States is not running out of technologies to improve energy efficiency and economic and environmental performance, and will not run out in the future. The study shows that many of the technologies have important non-energy benefits, ranging from reduced environmental impact to improved productivity. Several technologies have reduced capital costs compared to the current technology used by those industries. Non-energy benefits such as these are frequently a motivating factor in bringing technologies such as these to market.

Further evaluation of the profiled technologies is still needed. In particular, further quantifying the nonenergy benefits based on the experience from technology users in the field is important. Interactive effects and inter-technology competition have not been accounted for and ideally should be included in any type of integrated technology scenario, for it may help to better evaluate market opportunities.

While this report focuses on the United States, stateor region-specific analysis of technologies may provide further insights into opportunities specific for the region served. Regional specificity is determined by the type of users (i.e., industrial activities) in the region, as well as the available technology developers. Combining region-specific circumstances with technology evaluations provided in this report may lead to recognition of varying needs and the appropriate policy choices for regional (e.g., state or utility) agencies.

Our selection of a limited set of 54 technologies was an arbitrary constraint based on the funding available. A number of the initial technologies screened appeared very interesting and warrant further study, but were eliminated due to resource constraints. In addition, the initial list of candidate technologies should not be viewed as all-encompassing. The authors are aware that other promising existing technologies exist, and that by their nature new technologies will be continually emerging. Ideally, the effort reflected in this report should be the start of a continuing process that identifies and profiles the most promising emerging energy-efficient industrial technologies and tracks the market success for these technologies. An interactive database may be a better choice for it would allow the continuous updating of information, rather than providing a static snapshot of the industrial technology universe.

The study identifies and profiles many promising emerging energy-efficient industrial technologies, which can achieve high energy-savings, and have a good likelihood of success due to their economic, 
environmental, product quality, and other benefits. We recommend next steps that product developers and policy-makers could undertake for each of the most promising technologies. Follow-up assessments are needed to identify additional emerging technologies, and to track the emergence of the technologies profiled in this report.

Acknowledgements. The work of LBNL was supported by Pacific Gas \& Electric, the Office of Air and Radiation, U.S. Environmental Protection Agency and the Office of Industrial Technologies, U.S. Department of Energy, through the U.S. Department of Energy under Contract No. DE-AC0376SF00098. The work of ACEEE was supported by the New York State Energy Research \& Development Authority, the Northwest Energy Efficiency Alliance and the Iowa Energy Center.

\section{REFERENCES}

1. Alliance to Save Energy, American Council for an Energy-Efficient Economy, Natural Resources Defense Council, Tellus Institute, Union of Concerned Scientists, 1997. "Energy Innovations: A Prosperous Path to a Cleaner Environment," Washington, DC.

2. Belzer, D., Roop, J., Sands, R., Greene, D. 1995. "Energy Conservation Trends: Understanding the Factors Affecting Energy Conservation Gains and Their Implications for Policy Development,". Washington, DC: U.S. Department of Energy, Office of Policy.

3. Bernow, S.; Cory, K.; Dougherty, W.; Duckworth, M.; Kartha, S.; Ruth, M. 1999. “America's Global Warming Solutions,". A study for the World Wildlife Fund and Energy Foundation, Boston, MA: Tellus Institute.

4. Bureau of Economic Analysis, U.S. Dept. of Commerce, 2000. Summary Statistics from the BEA website, http://www.bea.doc.gov/.

5. Decanio, S. and Laitner, J. 1997. "Modeling Technological change in Energy Demand
Forecasting," Technological Forecasting and Social Change 55 pp.249-263.

6. Energy Information Administration (EIA), U.S. Department of Energy, 2000. Summary Statistics from the EIA website. www.eia.doe.gov

7. Energy Information Administration (EIA), U.S. Department of Energy, 1999. Annual Energy Outlook 2000. Energy Information Administration: Washington, DC.

8. Golove, W. H. and Schipper, L. 1996. "Longterm Trends in U.S. Manufacturing Energy Consumption and Carbon Dioxide Emissions," Energy 21 pp.683-692.

9. International Iron and Steel Institute, 2000. Statistical Data on continuous casting. http://www.worldsteel.org/trends_indicators/figu res_7.html

10. Martin, N. Worrell, E., Sandoval, A. Bode, J., Phylipsen, D. Ed. 1999. "Industrial Energy Efficiency Policies: Understanding Success and Failure," Workshop proceedings. Berkeley, CA: Lawrence Berkeley National Laboratory.

11. Martin, N., Worrell, E., Price, L.K., Ruth, M.B., Elliott, N., Shipley, A., Thorne, J., Nadel, S., 2000. "Emerging Energy-Efficient Industrial Technologies," Berkeley, CA/Washington, DC: LBNL/ACEEE.

12. Nadel, S., Rainer, L., Shepard, M., Suozzo, M., and Thorne, J., 1998. "Emerging Energy-Saving Technologies and Practices for the Buildings Sector," Washington, DC: ACEEE.

13. Worrell, E., Levine, M., Price, L., Martin, N., Van Den Broek, R., and Blok, K., 1997. "Potentials and Policy Implications of Energy and Material Efficiency Improvement," New York: United Nations Division for Sustainable Development, United Nations. 